\title{
ASSIMILATION OF SELENIUM, COPPER, AND ZINC IN RYE MALT
}

\author{
Kristīna Antoṇenko ${ }^{1, \#}$, Linda Briede ${ }^{2}$, Viesturs Kreicbergs ${ }^{1}$, Arturs Vīksna ${ }^{2}$, \\ and Konstantins Bavrins ${ }^{3}$ \\ ${ }^{1}$ Faculty of Food Technology, Latvia University of Life Sciences and Technologies, Jelgava, LV-3001, LATVIA \\ ${ }^{2}$ Faculty of Chemistry, University of Latvia, 1 Jelgavas Str., Rīga, LV-1004, LATVIA \\ ${ }^{3}$ Institute of Food Safety, Animal Health and Environment "BIOR", 3 Lejupes Str., Rīga, LV-1076, LATVIA \\ \# Corresponding author, antokrist@inbox.Iv
}

Communicated by Daina Kārkliṇa

\begin{abstract}
Trace elements selenium, copper, and zinc are essential minerals for the human body. One of the means to increase the micronutrient content in diets is to add them to food raw materials, for example, to enrich grain with micronutrients during malt production. To obtain rye malt, $3 \mathrm{~kg}$ grain was soaked in 10 I water with addition of three mineral salts - sodium selenate ( $\left.\mathrm{Na}_{2} \mathrm{SeO}_{4}\right)$, copper sulphate $\left(\mathrm{CuSO}_{4} 5 \mathrm{H}_{2} \mathrm{O}\right)$, and zinc sulphate $\left(\mathrm{ZnSO}_{4} 7 \mathrm{H}_{2} \mathrm{O}\right)$ at different concentrations and different combination of salts. The concentration of selenium, copper, and zinc was determined in rye malt. The obtained results were used to calculate the degree of assimilation of trace elements in rye malt. The interaction of trace elements selenium/copper and copper/zinc was studied. The total amount of selenium, copper, and zinc was analysed by inductively coupled plasma mass spectrometry (ICP-MS). Sample preparation for elemental analysis was performed by wet acid digestion in a closed microwave mineralisation system. The selenium assimilation degree in rye malt was within 10.6 to $12.2 \%$. Accordingly, copper assimilation was 32.8 to $38.0 \%$ and zinc 49.3 to $57.0 \%$. Simultaneous presence of selenium/copper and copper/zinc during rye grain soaking promoted the assimilation of each mineral, compared with only one mineral additive.
\end{abstract}

Key words: selenium, copper, zinc, assimilation, rye malt, germination.

\section{INTRODUCTION}

Micronutrients are essential elements used by plants in small quantities. For most micronutrients, crop uptake is less than $1 \mathrm{~kg} \cdot \mathrm{ha}^{-1}$. In spite of this low requirement, critical plant functions are limited if micronutrients are unavailable, resulting in plant abnormalities, reduced growth and lower yield (Butzen, 2010). Their specific biochemical roles cannot be substituted by other elements. In the absence of adequate amounts of these elements in plant tissues, crop growth and metabolic cycles will be impaired (Khoshgoftarmanesh et al., 2010). For example, trace amounts of selenium can promote growth in a variety of Se accumulator and non-accumulator plants. Studies have also shown that Se can protect plants from biotic and abiotic stresses (Tamas et al., 2010; Wong et al., 2012). Se can activate the antioxidant system by elevating GPX expression under abiotic stress conditions such as ultraviolet radiation, and low temperature. Also, supply of Se protects the plants from a variety of herbivores and pathogens, probably by volatile Se (dimethylselenide) emitted or Se elevated production of ethylene, jasmonic acid and other defense-related proteins
(Wong et al., 2012). Copper is an essential element for plants, animals, and people in small, but absolutely necessary quantities. An insufficient content of this element in the soil reduces the yield of crops, particularly cereals (Korzeniowska and Stanisławska-Glubiak, 2011). Copper is an activator of several enzyme systems in plants and functions in electron transport and energy capture by oxidative proteins and enzymes. It may play a role in vitamin A production. Vitamin A deficiency interferes with protein synthesis (Lohry, 2007). Zinc acts either as a metal component of enzymes or as a functional, structural, or regulatory cofactor of a large number of enzymes. More than 80 zinccontaining proteins have been reported. The rate of protein synthesis and the protein content in zinc-deficient plants are drastically reduced. The accumulation of amino acids and amides in these plants demonstrates the importance of zinc for protein synthesis. Zinc is an essential component of RNA polymerase and if the zinc is removed, the enzyme is inactivated. Zinc is also a constituent of ribosomes and is essential for their structural integrity. A decrease in protein content of zinc-deficient plants is also the result of enhanced rates of RNA degradation. Higher rates of RNase 
activity are a typical feature of zinc deficiency (Lohry, 2007; Mousavi et al., 2013).

Cereals, meats, and fish are the main sources of selenium in the human diet. Cereals and cereal products contain a wide range of selenium concentration, most being between $10-550 \mathrm{mg} \cdot \mathrm{kg}^{-1}$ on a fresh weight basis. Cereal grains produced in the Keshan county in China contain 3-7 mg. $\mathrm{kg}^{-1}$ selenium, whereas wheat grain produced in North and South Dakota in the US may contain more than $2000 \mathrm{Se} \mathrm{mg} \cdot \mathrm{kg}^{-1}$. In general, European wheats contain lower levels of selenium than North American wheats. Low selenium concentrations have been reported in Scandinavian countries with concentration in wheat ranging between $7-18 \mathrm{mg} \cdot \mathrm{kg}^{-1}$. Recent surveys of South Australian wheats reported a range of $5-720 \mathrm{Se} \mathrm{mg} \cdot \mathrm{kg}^{-1}$, with a mean value of $155 \mathrm{mg} \cdot \mathrm{kg}^{-1}$. Wheat samples from Manitoba of Canada had a mean selenium concentration of $760 \mathrm{mg} \cdot \mathrm{kg}^{-1}$. The nutritional minimum level both for animals and humans is about 50-100 Se $\mathrm{mg} \cdot \mathrm{kg}^{-1}$ in dry fodder/food, and intake below that may cause selenium deficiency (Tamas et al., 2010). The average copper concentration in the grain of wheat grown on different soils varies between 2.3 and $4.6 \mathrm{mg} \cdot \mathrm{kg}^{-1}$. In Poland the average copper concentration in winter wheat grain is $3.8 \mathrm{mg} \cdot \mathrm{kg}^{-1}$ and in spring barley is $4.8-5.4 \mathrm{mg} \cdot \mathrm{kg}^{-1}$ (Właśniewski et al., 2014). Cu concentration in wheat grain in England is $3.9-5.4 \mathrm{mg} \cdot \mathrm{kg}^{-1}$, Iran $-5.5 \mathrm{mg} \cdot \mathrm{kg}^{-1}$, Canada - $4.1 \mathrm{mg} \cdot \mathrm{kg}^{-1}$, Sweden - 3.5-5 $\mathrm{mg} \cdot \mathrm{kg}^{-1}$, and the USA - $4.1 \mathrm{mg} \cdot \mathrm{kg}^{-1}$ (Korzeniowska and StanisławskaGlubiak, 2011). In Central Asia, Zn concentration in wheat has been reported to be between $20 \mathrm{mg} \cdot \mathrm{kg}^{-1}$ and $39 \mathrm{mg} \cdot \mathrm{kg}^{-1}$ (Morgounov et al., 2007). Most cereals have an intermediate level of zinc, $\mathrm{Zn}$ concentration in whole-grain cereal (wheat, maize, brown rice, etc.) ranged from $5-32 \mathrm{mg} \cdot \mathrm{kg}^{-1}$ (Brown et al., 2011). The main aim of this research was to determine the degree of assimilation of selenium, copper, and zinc content in rye malt.

\section{MATERIALS AND METHODS}

Plant material. The research object was rye grain (variety 'Kaupo') from Ltd. "Naukšēni". Rye grains of $96 \%$ viability were soaked for $48 \mathrm{~h}$ at temperature $6.6-11.7{ }^{\circ} \mathrm{C}$ and germinated $72 \mathrm{~h}$ at temperature $6-15^{\circ} \mathrm{C}$. Twenty samples of rye malt were prepared. The experiments were perfomed in three replications. To obtain rye malt, $3 \mathrm{~kg}$ grain was soaked in $10 \mathrm{~L}$ water with addition of three mineral salts sodium selenate $\left(\mathrm{Na}_{2} \mathrm{SeO}_{4}\right)$, copper sulphate $\left(\mathrm{CuSO}_{4}\right.$ $\left.5 \mathrm{H}_{2} \mathrm{O}\right)$, and zinc sulphate $\left(\mathrm{ZnSO}_{4} 7 \mathrm{H}_{2} \mathrm{O}\right)$ at different concentrations and in different combinations (Table 1). As a control, samples without microelement additives were used in all experimental series. After germination the grain was rinse with distilled water and dried in an oven for 24 hours at temperature $60-112{ }^{\circ} \mathrm{C}$ in a triple deck kiln and ground with a laboratory mill fitted with a $0.4 \mathrm{~mm}$ sieve. Moisture of malt samples ranged from $7.2 \%$ till $8.9 \%$.

Mineralisation of rye malt samples. Microwave assisted wet acid digestion was used for mineralisation of samples.
CONCENTRATION OF MICROELEMENTS IN WATER

\begin{tabular}{l|l|c|c|c|c}
\hline \multirow{2}{*}{$\begin{array}{c}\text { Abbreviation } \\
\text { of samples }\end{array}$} & \multicolumn{1}{c|}{$\begin{array}{c}\text { Used mineral } \\
\text { salts }\end{array}$} & \multicolumn{4}{|c}{$\begin{array}{c}\text { Concentration of microelements } \\
\text { in solutions used } \\
\left.\text { (mg.1 } 1^{-1}\right)\end{array}$} \\
\cline { 3 - 6 } & & $\mathrm{K}$ & 1 & 2 & 3 \\
\hline $\mathrm{I}$ & $\mathrm{Se}\left(\mathrm{Na}_{2} \mathrm{SeO}_{4}\right)$ & 0 & 5 & 8.5 & 17 \\
$\mathrm{II}$ & $\mathrm{Cu}\left(\mathrm{CuSO}_{4} 5 \mathrm{H}_{2} \mathrm{O}\right)$ & 0 & 10 & 20 & 50 \\
$\mathrm{III}$ & $\mathrm{Zn}\left(\mathrm{ZnSO}_{4} 7 \mathrm{H}_{2} \mathrm{O}\right)$ & 0 & 10 & 50 & 100 \\
$\mathrm{IV}$ & $\mathrm{Se}\left(\mathrm{Na}_{2} \mathrm{SeO}_{4}\right)$ & 0 & 8.5 & 0 & 8.5 \\
& $\mathrm{Cu}\left(\mathrm{CuSO}_{4} 5 \mathrm{H}_{2} \mathrm{O}\right)$ & 0 & 0 & 20 & 20 \\
$\mathrm{~V}$ & $\mathrm{Zn}\left(\mathrm{ZnSO}_{4} 7 \mathrm{H}_{2} \mathrm{O}\right)$ & 0 & 50 & 0 & 50 \\
& $\mathrm{Cu}\left(\mathrm{CuSO}_{4} 5 \mathrm{H}_{2} \mathrm{O}\right)$ & 0 & 0 & 20 & 20
\end{tabular}

T a ble 2

MICROWAVE ASSISTED WET MINERALISATION PROGRAMME OF RYE MALT SAMPLES

\begin{tabular}{l|c|c|c}
\hline Step & Power, $\mathrm{W}$ & Ramp time, min & Holding time, min \\
\hline 1 & 600 & 10 & 5 \\
2 & 400 & 5 & 25 \\
3 & 0 & 2 & 20
\end{tabular}

This mineralisation method used closed Teflon vessels as selenium is a volatile element. Sample digestion was performed with a MULTIWAVE 3000 (Anton Paar) $1400 \mathrm{~W}$ microwave accelerated reaction system and $100 \mathrm{~mL}$ Teflon XF100 $\left(\mathrm{p}_{\max }=100 \mathrm{bar}, \mathrm{t}_{\max }=260^{\circ} \mathrm{C}\right)$ closed-system vessels using an eight-vessel rotor.

All plastic vessels were washed with an appropriate detergent, immersed in $5 \% \mathrm{HNO}_{3}$ for $24 \mathrm{~h}$ and rinsed with ultrapure water (18.2 M $\mathrm{cm}^{-1}$, Millipore Simplicity), prior to use. Approximately $0.2 \mathrm{~g}$ with precision $0.0001 \mathrm{~g}$ of each powdered sample was weighed into $100 \mathrm{ml}$ microwave Teflon vessels and $7 \mathrm{~mL}$ of concentrated nitric acid (freshly sub-boiling distilled) and $2 \mathrm{ml}$ of hydrogen peroxide (Merck, suprapure) were added to each vessel. The vessels were left open for two hours before sealing to allow samples to predigest, and were then positioned inside the microwave digestion system for a three-step microwave temperature program (Table 2). After cooling, digested sample solutions were transferred to $50 \mathrm{ml}$ plastic tubes and diluted up to $25 \mathrm{ml}$ with deionised water $\left(18.2 \mathrm{M} \Omega \cdot \mathrm{cm}^{-1}\right.$, Milipore Simplicity). Sample blanks were used for each mineralisation set. Approximately $0.5 \mathrm{~g}$ with precision $0.0001 \mathrm{~g}$ of each powdered rye malt sample was weighed into a quartz crucible and after preashing on a hot plate were mineralised in a programmable muffle oven at $550{ }^{\circ} \mathrm{C}$ for six hours. Finally, the ash was transferred to $50 \mathrm{ml}$ plastic tubes and diluted up to $45 \mathrm{ml}$.

Inductively coupled plasma mass spectrometry (ICPMS). A standard Agilent 7700x ICP-MS with a Micromist nebuliser was used for the determination of zinc, selenium, and copper in all rye malt samples. The operating conditions used for the analysis of samples are shown in Table 3. The Octopole Reaction System (ORS3) of the $7700 \times$ ICP-MS 
ICP-MS OPERATING PARAMETERS FOR THE DETERMINATION OF Se, Zn AND Cu IN RYE MALT SAMPLES

\begin{tabular}{lcc}
\hline \multicolumn{1}{c|}{ RF power, W } & 1300 \\
\hline Sampling depth, $\mathrm{mm}$ & 8 \\
Carrier gas flow, $1 \cdot \mathrm{min}^{-1}$ & 0.60 \\
Dilution gas flow, $1 \cdot \mathrm{min}^{-1}$ & 0.40 \\
He cell gas flow, $1 \cdot \mathrm{min}^{-1}$ & 0.004 \\
Number of replicates & 3
\end{tabular}

was operated in helium collision mode (He mode) and without an ORS3 cell. For the ICP-MS analysis, a MassHunter Workstation program and its subprograms - Instrument Control and Offline Data Analysis were used. For quantitative determinations by ICP-MS, a linear six-point calibration method was used. Stability of the analysis system was checked by using two standard solutions after ten replicates. For the preparation of standard solutions for quality checking and producing a calibration graph, TraceCERT® CRMs multi-element standard solution V for ICP $\left(10 \mathrm{mg} \cdot \mathrm{l}^{-1}\right.$ in $10 \% \mathrm{HNO}_{3}$ ) from SigmaAldrich and Selenium standard solution $\left(990 \pm 7 \mathrm{mg} \cdot 1^{-1}\right.$ in $2-3 \%$ HNO3), from Merck (Suprapur) were used.

Statistical analysis. The statistical analyses of data were carried out using Microsoft Excel for Windows 7.0 (Microsoft Corporation, Redmond, WA). Mean value, standard deviations and significant values were calculated. $P$-values $<0.05$ were regarded as significant.

\section{RESULTS}

To determine trace element $(\mathrm{Se}, \mathrm{Cu}, \mathrm{Zn})$ assimilation in rye malt, rye grain was soaked in varying concentrations of selenium, copper, and zinc salt solutions (Table 1).

Concentration of selenium in rye malt was determined by ICP-MS for experiment series - I. The obtained results (Fig. 1) showed that concentration of selenium in rye malt depended on the selenium concentration in solution. When the added concentration of selenium was $5 \mathrm{mg} \cdot \mathrm{l}^{-1}$, concentration of selenium in rye malt increased 36 times compared to the control sample, and at concentration of 8.5 and 17 $\mathrm{mg} \cdot \mathrm{l}^{-1}$ by 68 and 138 times, respectively.

Copper concentration was determined in series II. At copper concentration in solution of $10 \mathrm{mg} \cdot \mathrm{kg}^{-1}$ copper concentration increased 5.4 times, compared to the control sample. When the added copper concentration in solution was 20 and $50 \mathrm{mg} \cdot \mathrm{l}^{-1}$, concentration of copper in rye malt increased 8.3 and even 20 times, respectively (Fig. 2).

The concentration of zinc in rye malt samples was determined in series III. Zinc concentrations in solution of 10 , 50 , and $100 \mathrm{mg} \mathrm{L}^{-1}$ increased $\mathrm{Zn}$ concentration in rye malt $1.8,4.4$, and 7.6 times, respectively, compared with the control (Fig. 3).

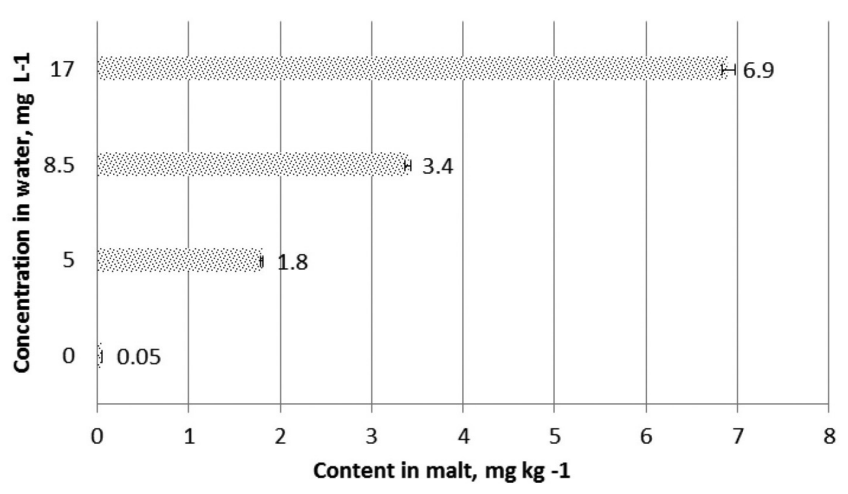

Fig. 1. Dependence of Se concentration in rye malt from the Se concentration in the soaking solution.

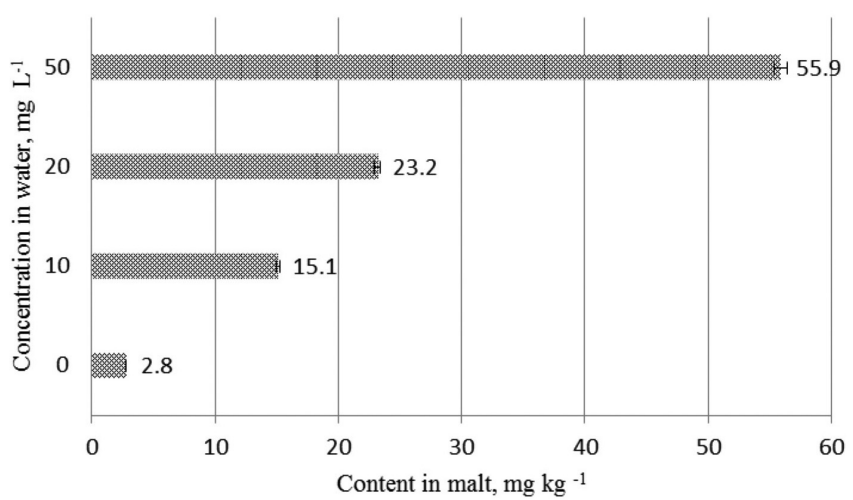

Fig. 2. Dependence of $\mathrm{Cu}$ concentration in rye malt on $\mathrm{Cu}$ concentration in the soaking solution.

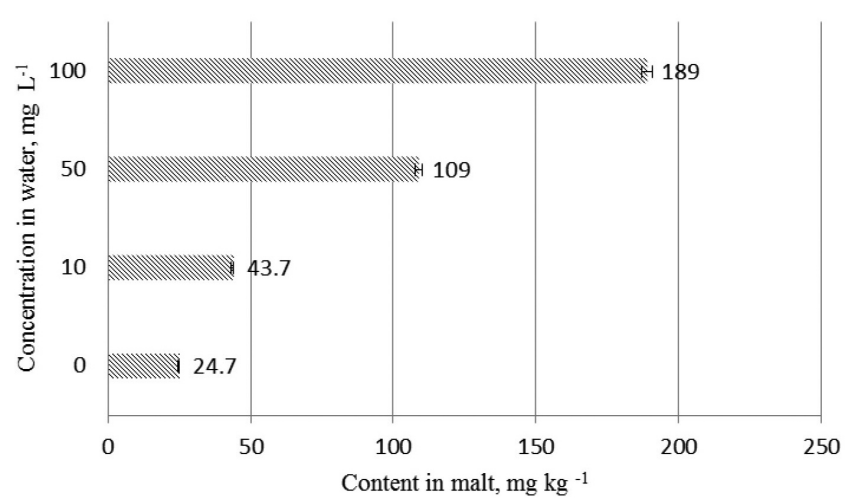

Fig. 3. Dependence of $\mathrm{Zn}$ concentration in rye malt on $\mathrm{Zn}$ concentration in the soaking solution.

The next step in the study was investigation of effect of two trace element combinations $(\mathrm{Se} / \mathrm{Cu}$ and $\mathrm{Cu} / \mathrm{Zn})$ in the soaking solution of rye to evaluate their interactions in the assimilation process. In the fourth series (IV - Se/Zn), solutions contained added selenium and zinc in different combinations: only with selenium addition (IV -1 ), only with copper addition (IV - 2) and with addition of selenium and copper salts (IV - 3). The obtained results compared with the control rye malt sample (IV - K) are shown in Figure 4. Similarly, we prepared a fifth experiment series (V $\mathrm{Cu} / \mathrm{Zn}$ ) with soaking water solutions using copper and zinc addition. The obtained results are presented in Figure 5. The concentrations of added amounts of $\mathrm{Se}, \mathrm{Cu}$ and $\mathrm{Zn}$ were op- 


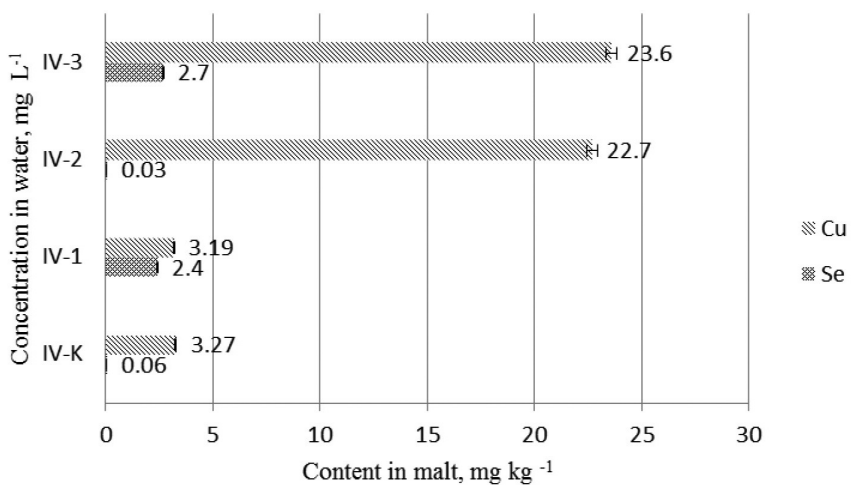

Fig. 4. Dependence of selenium and copper concentration in rye malt on $\mathrm{Se} / \mathrm{Cu}$ concentrations in the soaking solutions. IV-K: control rye malt sample; IV - 1: $\mathrm{Cu}\left(0 \mathrm{mg} \cdot \mathrm{l}^{-1}\right)$ and $\mathrm{Se}\left(8.5 \mathrm{mg} \cdot \mathrm{l}^{-1}\right)$ in soaking water; IV $-2: \mathrm{Cu}$ $\left(20 \mathrm{mg} \cdot \mathrm{l}^{-1}\right)$ and Se $\left(0 \mathrm{mg} \cdot \mathrm{l}^{-1}\right)$ in soaking water; IV $-3: \mathrm{Cu}\left(20 \mathrm{mg} \cdot \mathrm{l}^{-1}\right)$ and Se $\left(8.5 \mathrm{mg} \cdot \mathrm{l}^{-1}\right)$ in soaking water.

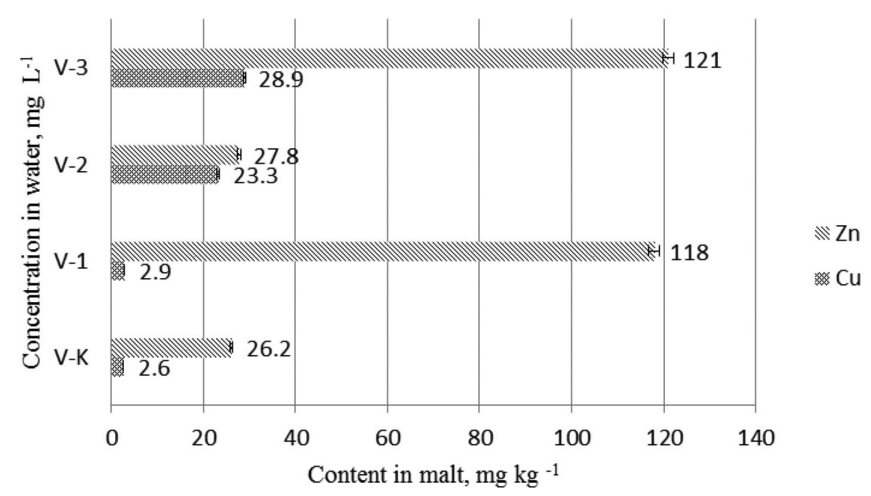

Fig. 5. Dependence zinc and copper concentration in rye malt on $\mathrm{Zn} / \mathrm{Cu}$ concentrations in the soaking solutions. $\mathrm{V}-\mathrm{K}$ : control rye malt sample; $\mathrm{V}-1: \mathrm{Zn}\left(50 \mathrm{mg} \cdot \mathrm{l}^{-1}\right)$ and $\mathrm{Cu}\left(0 \mathrm{mg} \cdot \mathrm{l}^{-1}\right)$ in soaking water; $\mathrm{V}-2: \mathrm{Zn}$ $\left(0 \mathrm{mg} \cdot \mathrm{l}^{-1}\right)$ and $\mathrm{Cu}\left(20 \mathrm{mg} \cdot \mathrm{1}^{-1}\right)$ in soaking water; $\mathrm{V}-3: \mathrm{Zn}\left(50 \mathrm{mg} \cdot \mathrm{1}^{-1}\right)$ and $\mathrm{Cu}\left(20 \mathrm{mg} \cdot \mathrm{l}^{-1}\right)$ in soaking water.

timised from the results of single element additions in the soaking water solution.

Assimilation efficiency of microelements was calculated from ICP-MS analyses results (Table 4).

\section{DISCUSSION}

In the current study, mean concentration of selenium in rye grain that was soaked in deionised water was $0.05 \mathrm{mg} \cdot \mathrm{kg}^{-1}$. Such an amount of selenium is common in Europe-grown grains and is significantly lower than in grain grown in America. (Tamas et al., 2010; Dūma, 2010). The selenium concentration in solution was correlated to the selenium concentration in rye malt $(p<0.05)$. Selenium accumulation in malt was proportional to its concentration in solution. The obtained results were similar to results of other studies (Lintschinger et al., 1997; Dūma, 2010).

Copper concentration in deionised water soaked rye malt was $2.8 \mathrm{mg} \cdot \mathrm{kg}^{-1}$ (Fig. 2), which was significantly higher $(p<0.05)$ compared to the selenium concentration $(0.05$ $\left.\mathrm{mg} \cdot \mathrm{kg}^{-1}\right)$ in rye malt. Similarly, selenium, copper concentra-
ASSIMILATION EFFICIENCY OF SOME MICROELEMENTS IN RYE GRAIN

\begin{tabular}{|c|c|c|c|c|}
\hline $\begin{array}{l}\text { Micro- } \\
\text { elements }\end{array}$ & & Sample 1 & Sample 2 & Sample 3 \\
\hline \multirow[t]{2}{*}{$\mathrm{Se}$} & $\begin{array}{l}\text { Concentration in bathing } \\
\text { solution, } \mathrm{mg} \cdot \mathrm{l}^{-1}\end{array}$ & 5 & 8.5 & 17 \\
\hline & Assimilation efficiency, $\%$ & 10.6 & 12 & 12.2 \\
\hline \multirow[t]{2}{*}{$\mathrm{Cu}$} & $\begin{array}{l}\text { Concentration in bathing } \\
\text { solution, } \mathrm{mg} \cdot \mathrm{l}^{-1}\end{array}$ & 10 & 20 & 50 \\
\hline & Assimilation efficiency, $\%$ & 36.9 & 30.6 & 30.8 \\
\hline \multirow[t]{2}{*}{$\mathrm{Zn}$} & $\begin{array}{l}\text { Concentration in bathing } \\
\text { solution, } \mathrm{mg} \cdot \mathrm{l}^{-1}\end{array}$ & 10 & 50 & 100 \\
\hline & Assimilation efficiency, \% & 57 & 50.6 & 49.3 \\
\hline
\end{tabular}

tion in rye malt depended on its concentration in solution. The copper concentration in solution was correlated to the copper concentration in rye malt $(p<0.05)$.

Quantitative and qualitative harvest culture is heavily dependent on the concentration of zinc in soil (Mousavi et al., 2013). The concentration of zinc in the plant is significantly higher than copper and selenium concentration (Morgounov et al., 2007; Thomas et al., 2010; Brown et al., 2011). The results of $\mathrm{Zn}$ assimilation (Fig. 3) are similar to selenium and copper, and also $\mathrm{Zn}$ concentration in malt was proportional to the concentration of $\mathrm{Zn}$ concentration in solution. Compared with control samples, the increases of zinc concentration in malt was not as large as in the case of selenium and copper, which can be explained by the higher zinc concentration in the control.

In nature plants and soil waters contain many trace elements, which facilitate or impede mutual assimilation (Orlov, 1998; Buligin et al., 2007). The results (Fig. 4) of the fourth series (IV-Se/Zn) showed that addition of both Se and $\mathrm{Zn}$ to the solution used for soaking grains slightly $(p<$ 0.05 ) increased $\mathrm{Cu}$ and $\mathrm{Se}$ assimilation (IV-3) in rye malt, compared with samples where solutions had single micro-nutrient additions: selenium (IV-1) or copper (IV-2). Selenium assimilation in rye malt increased up to $12 \%$ and for copper $-4 \%$.

Similar results (Fig. 5) were obtained for the fifth series $(\mathrm{IV}-\mathrm{Zn} / \mathrm{Cu})$ of rye malt samples. These experiments also showed that simultaneous addition of $\mathrm{Cu}$ and $\mathrm{Zn}$ in the soaking solution sligthly promoted assimilation of both elements in the rye malt, compare with the single element addition solutions. This might be explained by functionally copper-deficiency of zinc-deficient cells, although they hyper accumulate copper up to 50-fold over normal levels. Malasarn (2013) suggested that zinc-deficient cells sequester copper in a bio-unavailable form, perhaps to prevent mismetallation sites.

It is known that grains do not accumulate selenium (Terry et al., 2000). In this study selenium intake was calculated and analysed in the rye grain germination process, i.e. the pro- 
portion of available selenium in solution that was assimilated by grain. The obtained results are shown in Table 4. The most effective accumulation of selenium was observed at the highest Se concentration in solution $-17 \mathrm{mg} \cdot \mathrm{l}^{-1}$. Rye grain at this concentration accumulated $12.2 \%$ of selenium present in solution, whereas at the lowest selenium concentration in the solution $\left(5 \mathrm{mg} \cdot \mathrm{l}^{-1}\right)$ grains assimilated $10.6 \%$ of the selenium. The different selenium intake in rye grain can be explained by selenium consumption by grain at necessary quantity at increased selenium concentration in the solution, because of biological processes (Dūma, 2010).

Copper assimilation efficiency was significantly higher than that of selenium (Table 4). This is due to copper accumulation conditions in plants (Właśniewski et al., 2014). The low micro-nutrient concentration in plant reproductive organs is due to the protective function that protects plant from assimilation of trace elements in larger amounts in these organs (Titov et al., 2007). Results presented in Table 4 showed that higher assimilation efficiency of $\mathrm{Cu}$ in malt $(36.9 \%)$ was obtained in the soaking solution with the highest $\mathrm{Cu}$ concentration. At a lower concentration of copper (20 and $50 \mathrm{mg} \cdot \mathrm{l}^{-1}$ ) in solution, assimilation of $\mathrm{Cu}$ in rye malt was $30.6 \%$ and $30.8 \%$, respectively. Similar results were obtained for zinc assimilation efficiency in rye. Zinc and copper are essential trace elements that plants also accumulate (Brown et al., 2011). As seen from Table 4, the highest assimilation effect of $\mathrm{Zn}(57 \%)$ in rye malt was observed in soaking solution with the lowest concentration (10 $\mathrm{Zn} \mathrm{mg} \cdot \mathrm{l}^{-1}$ ), compared to $49.3 \%$ of zinc assimilated at the highest concentration of zinc in solution $\left(100 \mathrm{mg} \cdot \mathrm{l}^{-1}\right)$. This different zinc intake in rye grains is due to a stronger connection to the cell membranes at lower concentrations of micro elements in the environment. It is known that with increase of zinc concentration, links with the cells will weaken significantly.

\section{CONCLUSIONS}

The concentration of microelements $(\mathrm{Se}, \mathrm{Cu}$, and $\mathrm{Zn}$ ) in rye malt was correlated with the selenium, copper, and zinc concentration in solution used for soaking rye grain.

The observed increase of selenium concentration in rye malt was 36,68 , and 138 times higher than in the control sample, using soaking solutions with selenium concentrations 5, 8.5, and $17 \mathrm{mg} \cdot \mathrm{l}^{-1}$, respectively. The observed increase of copper and zinc amounts in rye samples was approximately 8 and 18 times lower, respectively, compared with selenium.

It can be concluded that most efficient migration of microelements from solution to rye malt was observed for Zn. Rye grains accumulate about 49.3 to $57 \%$ of total zinc amount added in deionised water. Copper assimilation efficiency was $30.6-36.9 \%$, and for selenium only 10.6$12.2 \%$.
Simultaneous presence of selenium/copper and copper/zinc during rye grain soaking slightly promoted assimilation of the studied minerals, compared with single mineral addition.

\section{REFERENCES}

Brown, K. H., Wuehler, S. E., Peerson, J. M. (2011).The importance of zinc in human nutrition and estimation of the global prevalence of zinc deficiency. Food Nutr. Bull., 22 (2), 113-125.

Buligin, S. J., Demishev, L. F., Doronin, V. A., Zarisnak, A. S., Pascenko, J. V., Turovskii, J. E., Fateev, A. I., Jakovenko, M. M., Kordin, A. I. (2007). Microelements in Agriculture [Булыгин, С. Ю., Демишев, Л. Ф., Доронин, В. А., Заришняк, А. С., Пащенко, Я. В., Туровский, Ю. Е., Фатеев, А. И., Яковенко М. М., Кордин А. И. Микроэлементы в сельском хозяйстве]. Sich, Dnepropetrovsk. 100 pp. (in Russian).

Butzen, S. (2010). Micronutrients for Crop Production. Crop Insights, 20 (9), $2-4$.

Dūma, M. (2010). The qualitative evaluation of grain fortified with selenium. Doctoral thesis. Latvia University of Agriculture, Jelgava, pp. 50-95.

Khoshgoftarmanesh, A. H., Schulin, R., Chaney, R. L., Daneshbakhsh, B., Afyuni, M. (2010). Micronutrient-efficient genotypes for crop yield and nutritional quality in sustainable agriculture: A review. Agron. Sustain. Dev., 30, 83-107.

Korzeniowska, J., Stanisławska-Glubiak, E. (2011).The effect of foliar application of copper on content of this element in winter wheat grain. Polish J. Agron., 4, 3-6.

Lintshinger, J., Fuchs, N., Moser, H., Jäger, R., Hlebeina, T., Markolin, G., Gössler, W. (1997). Uptake of various trace elements during germination of wheat, buckwheat and quinoa. Plant Food Human Nutr., 50, 223-237.

Lohry, R. (2007). Micronutrients: Functions, Sources and Application Methods. In: Indiana CCA Conference Proceedings. Sioux City, Iowa.

Malasarn, D., Kropat, J., Hsieh, S. I., Finazzi, G., Casero, D., Loo, J. A., Pellegrini, M., Wollman, F., Merchant, S. S. (2013). Zinc deficiency impacts $\mathrm{CO}_{2}$ assimilation and disrupts copper homeostasis in Chlamydomonasreinhardtii. J. Biol. Chem., 288 (15), 10672-10683.

Morgounov, A., Gómez-Becerra, H. F., Abugalieva, A., Dzhunusova, M., Yessimbekova, M., Muminjanov, H., Zelenskiy, Y., Cakmak, I. (2007). Iron and zinc grain density in common wheat grown in Central Asia. Int. J. Plant Breed., 155 (1), 193-203.

Mousavi, S. R., Galavi, M., Rezaei, M. (2013). Zinc (Zn) Importance for crop production: Review. Int. J. Agron. Plant Prod., 4 (1), 64-68.

Orlov, D. S. (1998). Microelements in soil and live organism [Орлов, Д. С. Микроэлементы в почвах и живых организмах]. Soros Education Journal [Соросовский образовательный журнал], 1, 61-68 (in Russian).

Tamas, M., Mandoki, Z., Csapo J. (2010). The role of selenium content of wheat in the human nutrition. A literature review. Acta Univ. Sapientiae, Alimentaria, 3, 5-34.

Terry, N., Zayed, A. M., de Souza, M. P., Tarun, A. S. (2000). Selenium in higher plants. Annu. Rev. Plant Physiol. Mol. Biol., 51, 401-432.

Titov, A. F., Talanova, V. V., Kaznina, N. M., Laidinen, G. F. (2007). The Resistance of Plants to Heavy Metals [Титов, А. Ф., Таланова, В. В., Казнина, Н. М., Лайдинен, Г. Ф. Устойчивость растений к тяжельмм металлам]. Karelskii Scientific Centre of Russian Academy of Sciences, Petrozavodsk. 172 pp. (in Russian).

Wang, Y., Wang, X., Wong, Y. (2012). Proteomics analysis reveals multiple regulatory mechanisms in response to selenium in rice. J. Proteomics, 75 (6), 1849-1866. 
Właśniewski, S., Kaniuczak, J., Hajduk, E., Nazarkiewicz M. (2014). Influence of limiting and mineral fertilization on the copper content in grain of spring barley (Hordeum vulgare L.) and winter wheat (Triti Cumaestivum L.) cultivated on loessial soil. J. Elem., 821-832.

Received 5 October 2016

Accepted in the final form 15 November 2017

\section{SELĒNA, VARA UN CINKA ASIMILĀCIJA RUDZU IESALĀ}

Mikroelementi selēns, varš un cinks ir nozīmīgi minerāli cilvēka ķermenī. Viena no iespējām, kā palielināt mikroelementu saturu cilvēku uzturā, ir pievienot tos pārtikas izejvielās, piemēram, bagātināt graudus ar mikroelementiem iesala ražošanas laikā.

Lai iegūtu rudzu iesalu, $3 \mathrm{~kg}$ graudus mērcēja 101 ūdens, kurā pievienoja trīs dažādus minerālu sāḷus — nātrija selenātu $\left(\mathrm{Na}_{2} \mathrm{SeO}_{4}\right)$, vara sulfātu $\left(\mathrm{CuSO}_{4} 5 \mathrm{H}_{2} \mathrm{O}\right)$ un cinka sulfātu $\left(\mathrm{ZnSO}_{4} 7 \mathrm{H}_{2} \mathrm{O}\right)$ dažāāās koncentrācijas un kombinācijās. Rudzu iesalam tika noteikts selēna, vara un cinka saturs, kā arī aprēkināta šo mikroelementu asimilācijas pakāpe. Tika pētīta savstarpēja mijiedarbība starp mikroelementiem selēns/varš un varš/cinks. Kopējais selēna, vara un cinka saturs tika noteikts ar induktīvi saistîtās plazmas masspektrometrijas metodi (ICP-MS). Selēna asimilācijas pakāpe rudzu graudos sastādīja no 10,6 līdz 12,2\%. Savukārt vara asimilācija no 32,8 līdz 38,0\%, bet cinka: 49,3-57,0\%. Vienlaicīga mikroelementu selēna/vara un vara/cinka klātbūtne rudzu graudu mērcēšanā veicināja šo minerālvielu savstarpējo asimilāciju, salīdzinot to ar tikai vienas minerālvielas piedevu. 